УДК 347.793:656.071.4

DOI https://doi.org/10.51989/NUL.2021.6.2

\title{
ПРАВОВИЙ СТАТУС ПОРТОВИХ ОПЕРАТОРІВ - СТИВІДОРІВ У МОРСЬКИХ ПОРТАХ
}

\author{
Балобанов Олександр Олегович, \\ кандидат юридичних наук, \\ професор кафедри морського права \\ Одеського національного морського університету \\ Пальченко Алла Анатоліївна, \\ старший викладач кафедри морського права \\ Одеського національного морського університету
}

Правовий статус портових операторів - стивідорів у морських портах України регулюється за допомогою Кодексу торгівельного мореплавства, Закону України «Про морські порти України» та Правил надання морських послуг у портах України. Портова діяльність $\epsilon$ складовою сфери торговельного мореплавства, і її правове регулювання пов'язане із діяльністю, що входить у поняття торговельне мореплавство. Світова транспортна система, до якої входять порти, функціонує в умовах загострення конкуренції між національними системами, між різними видами транспорту, а саме між морським та наземним. У мультимодальному режимі сьогодні працюють і контейнеризовані, і неконтейнеризовані лінії. Стивідорна діяльність включає виробничо-технологічну й організаційно-економічну складові. На території кожного морського порту працюють державні стивідори. Портовий оператор, оператор термінала надають послуги з вантажних операцій із вантажами, що перевозяться водним, залізничним, автомобільним та трубопровідним видами транспорту, а також інших пов'язаних з цим робіт, на замовлення клієнта. У морських портах України перелік портових операторів, операторів терміналів у кожному морському порту, а також перелік послуг, які вони надають, визначається в реєстрі морських портів України. Зважаючи на цю норму, виконавцями вантажних операцій можуть виступати лише портові оператори, оператори терміналів, номенклатура яких обмежена реєстром.

Ключові слова: торгове мореплавство, стивідорна кампанія, портовий оператор, морський порт, оператор термінала.

\section{Balobanov Oleksandr, Palchenko Alla. Legal status of port stevedoring operators in seaports}

The legal status of port stevedoring operators in the seaports of Ukraine is regulated by the Code of Merchant Shipping, the Law of Ukraine "On Seaports of Ukraine" and the Rules for the provision of sea services in the ports of Ukraine. Port activity is an integral part of the sphere of merchant shipping and its legal regulation is associated with activities that are part of the concept of merchant shipping. The world transport system, which includes ports, operates in conditions of intensified competition between national systems, between different modes of transport, namely between sea and land. Both containerized and non-containerized lines operate in multimodal mode today. Working as part of a multimodal scheme requires seaports - stevedores to be competitive, both in relation to the subjects of movement of goods, and to the ports included in other logistics chains. Stevedoring activities are part of economic activities. It should be considered as the activity of business entities, which is associated with the loading and unloading of ships, aimed at generating income, is regular, permanent, significant, that is, it coincides with the definition of entrepreneurial activity. Stevedoring activities include a production and technological component and an organizational and economic component. As a reality on the grounds of modernization in the development of the world port distribution system, the process of attracting private capital not only in the development of port infrastructure, but also in the actual stevedoring activities. State stevedores operate on the territory of each seaport. The port operator, the terminal operator provides services for freight operations with goods transported by water, rail, road and pipeline modes of transport, as well as other related 
work at the request of the client. That is, there are two definitions regarding the executor of cargo operations. These are the port operator and the terminal operator. In the seaports of Ukraine, the list of port operators, terminal operators in each seaport, as well as the list of services provided is determined in the register of seaports of Ukraine. Based on this rule, the executor of cargo operations can be only port operators, terminal operators, whose range is limited to the register.

Key words: merchant shipping, stevedoring company, port operator, seaport, terminal operator.

Постановка проблеми. Стратегія розвитку портів на базі реформування портової галузі має враховувати світові та європейські тенденції щодо організації портів як логістичних центрів світової торгівлі. У сфері поліпшення надання послуг портових операторів - стивідорів необхідно також усунення різноманітних недоліків, пов'язаних з залученням нових клієнтів та інвестицій. Виявляється необхідність чітко визначитися щодо правового регулювання стивідорської діяльності та шляхів її інвестування, розвитку, організації, а також потреба з'ясувати правовий статус Реєстру портових операторів у складі морських портів.

Огляд останніх досліджень та публікацій. Важливі питання розглядуваної проблеми висвітлювалися в працях вітчизняних учених, зокрема, у роботах О.М. Кібік, О.М. Кіфака, В.В. Коваля, О.М. Котлубая, О.П. Подцерковного та інших науковців. Водночас необхідність дослідження процесів господарювання в морських портах не втрачає своєї актуальності. Світова ринкова кон'юнктура постійно змінюється, процеси глобалізації та інтернаціоналізації поглиблюються, перед світом постають нові проблеми, зокрема, у вигляді світової пандемії COVID-19. Ці фактори впливають на всі сфери людського буття, на соціальний та економічний складники. Саме тому в умовах швидких економічних, правових, соціальних змін розгляд сучасних напрямів розвитку господарської діяльності в морських портах видається вельми цікавим та необхідним.

Завдання дослідження. Вивчення основних проблемних питань та напрямів розвитку та діяльності портових операторів - стивідорів. Дослідження світових тенденцій функціонування морегосподарського комплексу, аналіз правових засад та проблематики функціонування логістичних центрів світової морської торгівлі.
Основний матеріал дослідження. Посилення комерційної стивідорської функції портів, поряд з функціями адміністративною та безпековою, отримали в світі повне визнання, що, своєю чергою, перетворює їх на логістичні центри світової морської торгівлі. Останнім часом головним викликом портам-стивідорам $\epsilon$ формування світової транспортної системи, що забезпечує світову логістику. Із сучасної практики морські порти на міжнародному та європейському рівнях $\epsilon$ багатофункціональними об'єктами, які, з точки зору їхньої участі у логістичних процесах, забезпечують міжнародну торгівлю. Порти $\epsilon$ логістичними центрами, у яких поєднуються функції перевезення, перевантаження, зберігання та інших господарських операцій. У порту як логістичному центрі стикаються інтереси практично всіх суб'єктів морського бізнесу (судновласників, вантажовласників, стивідорів, сервісних організацій, контролюючих органів, тощо). Маємо деталізувати визначення порту як логістичного центру таким чином:

- Центр логістичного ланцюга, де починаються та завершуються правовідносини між суб'єктами світової торгівлі (наприклад, це місце переходу права власності на товар, кордон розподілу ризиків, обов'язків та витрат за правилами торгівлі);

- Логістичний центр, де стикаються функції перевезення, перевалки, зберігання, щодо обслуговування вантажів та транспортних засобів (перш за все морських суден);

- Центр зіткнення комерційних та юридичних інтересів осіб, що $€$ операторами зазначених засобів;

- Центр взаємодії різних видів транспорту, особливо під час мультимодальних перевезень;

- Центр прийняття організаційно-правових та управлінських рішень; 
- Центр, де здійснюється юридичне закріплення, оформлення правовідносин та розв'язання конфліктів інтересів через спеціальні договори або на основі нормативно-правових документів;

- Центр зіткнення функцій забезпечення безпеки та суто комерційних функцій;

- Центр зіткнення обов'язків держави прапору судна та держави порту;

- Центр, де контролюється виконання вимог міжнародних угод судновласн6иками та висвітлюються проблеми їх імплементації державами;

- Кордон митних, санітарних, безпекових, пошуково-рятувальних зон відповідальності, що встановлює держава порту.

Тобто, порт $\epsilon$, з одного боку, географічним місцем - з акваторією та територією за законом, а з іншого - транспортним комплексом, системою спеціалізованих послуг, що надаються у портовій виробничій зоні, з третього боку, логістичним центром, як у розумінні міжнародної торгівлі (ланцюга поставок), так і в розумінні логістичних послуг (переміщення, складування, сервісу).

Світова транспортна система, до якої входять порти, функціонує в умовах загострення конкуренції між національними системами, головним чином - між різними видами транспорту, а саме між морським та наземним. У мультимодальному режимі сьогодні працюють і контейнеризовані, і неконтейнеризовані лінії. Робота у складі мультимодальної схеми вимагає від морських портів - стивідорів бути конкурентоздатними як щодо суб'єктів переміщення товарів, так і щодо портів, що входять до інших логістичних ланцюгів.

Ще одним важливим впливом на порти $\epsilon$ активізація процесів економічної інтеграції держав та регіонів, що своєю чергою інтегрує порти у міжнародну і міжрегіональну економіку.

Таким чином, агресивність зовнішнього середовища стосовно портів зростає і ця тенденція зберігається, але, в будь-якому разі, ефективність порту визначається запитами клієнтів - продавців та покупців товарів на світовому ринку. У цих умовах порт-стивідор має розробити активну стратегію, яка дасть йому змогу отримати переваги за рахунок якості робіт та широ- кої диверсифікації послуг. Такі можливості дає розвиток як менеджменту, так і інфраструктури. Якщо раніше основним критерієм розвитку порту виступала саме його інфраструктура, то тепер ще й управління та інформаційна система. Головними суб'єктами, що спонукають та забезпечують розвиток, $\epsilon$ портові оператори, які працюють у його складі й надають стивідорські та інші послуги.

Така ситуація диктує необхідність забезпечити якісну нормативно-правову базу, що пов'язана з діяльністю портового господарства, перш за все стосовно стивідорів та стивідорської діяльності, портових операторів і послуг, що ними надаються, та терміналів, термінальних операцій, операторів терміналів. На жаль, законодавство України не повною мірою відповідає світовій практиці та реальним місцевим вимогам.

Стивідорна діяльність $€$ частиною господарської діяльності. Ї̈̈ слід розглядати як діяльність суб'єктів господарювання, що пов'язана з навантаженням-розвантаженням суден, направлена на отримання доходу, $\epsilon$ регулярною, постійною, суттєвою, тобто це цілком співпадає з визначенням підприємницької діяльності. Стивідорна діяльність включає виробничотехнологічну складову і організаційно-економічну складову. Як реальність з мотивів модернізації у розвитку світової портової системи розповсюдження отримав процес залучення приватного капіталу не тільки у розбудову інфраструктури порту, але й власне в стивідорну діяльність. Сьогодні у світі та в Європі $€$ різноманітні форми збільшення ролі приватного сектору у стивідорній діяльності. Вона торкається вантажно-розвантажувальних робіт, логістичних операцій, а також буксирування, швартування, агентських послуг. 3 урахуванням роботи в більшості випадків державних стивідорних кампаній та впливу держав через Адміністрацію портів, участь приватного сектору відображається через:

- створення спільного підприємства Адміністрацією порту та стивідорною кампанією;

- контракт між портовою владоюта приватними підприємствами для експлуатації окремих терміналів порту (менеджмент, управління майном); 
- передачу в концесію частини портових споруд або терміналу. Термінали передаються в концесію на певний строк приватній фірмі, яка фінансує структури та техніку, забезпечує експлуатацію та отримує прибуток відповідно до контракту;

- концесію, коли контракт укладається між державним власником та приватним вкладником капіталу, який фінансує, будує, експлуатує і отримує прибуток протягом встановленого періоду конкретний портовий термінал. За таких умов територія залишається у власності держави, якій повертаються усі споруди;

- оренду терміналів. На практиці використовується оренда трьох типів: довгострокова (20-50 років), короткострокова (3 місяці - 1 рік), разова (для розвантаження окремого судна). Європейськими портами встановлені певні правила для кожного типу оренди, основними умовами яких $є$ забезпечення конкуренції і виключення приватної монополії.

Великим судновласникам і вантажовласникам вигідно, коли стивідорні кампанії належать повністю або частково їм. Це гарантує повний обсяг стивідорних операцій, що забезпечує зайнятість та прибутковість. Тобто зазначені суб'єкти приводять з собою вантажопотік і самі з ним працюють.

Агентські кампанії також прагнуть вкладати капітал у стивідорний бізнес, як і стивідорні в агентський. Але в певних випадках створюється конфлікт інтересів між стивідором та судновласником, на користь якого має працювати агент.

Стивідорні кампанії Європейського типу перестають бути універсальними та спеціалізуються на видах оброблювальних вантажів, типах суден, та характеристиках ліній (до складу яких, зазвичай входять і стивідор).

У великих портах світу стивідорні кампанії об'єднуються в Асоціації, які представляють та відстоюють їхні інтереси перед судновласниками, профспілками, а також розробляють єдину політику щодо тарифів на стивідорні операції. Асоціації об'єднують стивідорні кампанії одного порту або групи портів.

Якщо говорити про державні портові оператори, то на території кожного мор- ського порту працюють державні стивідори. Наприклад, у порту «Південний» здійснює державну стивідорну діяльність держкомпанія «Морський торговельний порт (МТП) «Південний». ДП МТП «Південний» $\epsilon$ найбільшим (за вантажообігом) і найглибшим портом в Україні. Порт займає вигідне економіко-географічне розташування. Він знаходиться в самому центрі Причорномор'я, має вихід у регіон Середземного моря, близько розташований до основних залізничних магістралей держави, з щорічною навігацією і можливістю прийому сучасного тонажного флоту. Вказані переваги дають змогу здійснювати ефективні експортно-імпортні перевезення вантажів через порт України та збільшувати обсяги переробки транзитних вантажів для інших держав.

Незважаючи на складний інвестиційний клімат і недостатність власного капіталу, в Україні реалізуються інфраструктурні інвестиційні проекти, спрямовані на розвиток портової діяльності, залучаються з недержавних коштів, вітчизняних та іноземних інвесторів. Розвиваються схеми державно-приватного партнерства. Стрімкий розвиток портового господарства в умовах жорсткої конкуренції можливий лише в разі тісної співпраці порту із державою і залучення інвестицій у розвиток порту для досягнення максимальної ефективності. Отже, основні напрямки розвитку вантажних порту мають відповідати перспективам збільшення вантажопотоків, спиратися на економічні інтереси держави, порту та регіонів розташування. Таким чином, стратегія розвитку має бути спрямована насамперед на вирішення таких завдань:

- оптимізація структури управління;

- створення сучасної вантажної бази портів та портової інфраструктури;

- розвиток інвестиційно-інноваційної діяльності;

- залучення фінансових ресурсів; удосконалення тарифної політики;

- удосконалення системи митного контролю;

- підвищення ефективності функціонування портів;

- підвищення ролі соціальної складової в діяльності портів.

Урегулювання проблеми портового оператора важливе саме з точки зору 
конкурентної атмосфери та взаємодії з користувачами й Адміністрацією Порту. 3 приводу правового статусу портового оператора маємо численні коментарі, але суперечки ще мають місце. Основою чіткого визначення правового статусу Портового оператора має бути відокремлення його від інших суб'єктів портової діяльності, користувачів, порядку реєстрації, прив'язки до певних функцій, акваторії, території. Маємо визначатися через наукові дослідження, судові рішення та уточнення у законодавстві. На жаль, натепер повною мірою цього немає. В Україні основним законом, що регулює правовідносини у сфері мореплавства, $\epsilon$ Кодекс торговельного мореплавства України (далі - КТМ). Торгівельним мореплавством називається діяльність з використання суден для перевезення вантажів та іншого. Оскільки перевезень без перевалки, зберігання, накопичення обслуговування вантажів не може бути, то портова діяльність у визначенні морських законодавств світових держав та України є складовою сфери торговельного мореплавства. Слід відзначити і ст. 4 КТМ, яка відносить регулювання морських правовідносин не тільки до морського кодексу, а й до правил цивільного, адміністративного, господарського та іншого законодавства України [1]. Це положення цілком належить до портового регулювання, у якому портовий оператор $\epsilon$ центральним суб'єктом, тобто діяльність цього суб'єкта має бути врегульована не тільки спеціальними, а й загальними нормами права. У вказаному випадку спеціальні норми права сконцентровані в Законі України «Про морські порти України» та підзаконних актах щодо портової діяльності [2].

Портовий оператор, оператор термінала надають послуги з вантажних операцій з вантажами, що перевозяться водним, залізничним, автомобільним та трубопровідним видами транспорту, а також інших пов'язаних із цим робіт на замовлення клієнта. Тобто існують дві дефініції щодо виконувача вантажних операцій. Це портовий оператор та оператор термінала.

Оператор термінала, на відміну від визначення портового оператора - суб'єкт господарювання, що здійснює у морському порту вантажні операції, обслугову- вання та зберігання вантажів, обслуговування транспортних засобів, а також інші пов'язані з цим види господарської діяльності, за межами морського термінала. Тобто з визначення оператора термінала можна зробити висновок, що і він може бути віднесений до категорії суб'єктів стивідорської діяльності взагалі, але з використанням терміналів - тільки у співпраці з портовим оператором.

3 точки зору європейської практики визнається, що оператор терміналу може виконувати лише внутрішні термінальні операції, але не стивідорні, які з судном виконує портовий оператор. Якщо робиться така диференціація, то треба визначити ці поняття у законодавстві, але за явної потреби виробництва. Тим більше, оператор морського термінала $\epsilon$ особою, що здійснює його експлуатацію. Тобто експлуатація і операторство це взаємопов'язані поняття. Тому маємо окремо тлумачити саме поняття експлуатація морського термінала. Цю експлуатацію слід тлумачити як безпосереднє та безперешкодне володіння та користування морським терміналом, яке базується на певному речовому, зобов'язальному праві у кожному морському порту.

Відповідно до п. 3.1 Правил надання послуг у морських портах України, перелік портових операторів, операторів терміналів у кожному морському порту, а також перелік послуг, які вони надають, визначається в реєстрі морських портів України [3]. 3 огляду на цю норму, виконавцями вантажних операцій можуть виступати лише портові оператори, оператори терміналів, номенклатура яких обмежена реєстром. Ст. 6 Закону України «Про морські порти» передбачається обов'язковість ведення такого реєстру. Відомості, що вносяться до реєстру, включають, крім загальнопортових, такі: повне найменування, місцезнаходження, перелік причалів послуг, технічні характеристики термінала [2]. Ведення реєструпокладенонаАМПУ.Такимчином,де-юре на АМПУ покладена відповідальність за реєстрацію портових операторів та операторів терміналів за певними організаційно-технічними ознаками, а де-факто це й контроль за їхньою діяльністю. Достовірність та повноту інформації забезпечують самі суб'єкти господарювання, але АМПУ завжди може 
їі перевірити, що, на жаль, часто не відбувається. Хоча стивідорна діяльність, згідно з законодавством України не потребує ліцензування (крім обробки небезпечних вантажів), проте порядок у порту - справа АМПУ, і він безумовно включає уточнення інформації щодо суб'єктів портової діяльності.

Висновки. Таким чином, основними висновками з наведеного можна вважати те, що стратегія розвитку портів на базі реформування портової галузі має враховувати світові та європейські тенденції щодо організації портів як логістичних центрів світової торгівлі; маємо чітко визначитися щодо правового регулювання стивідорської діяльності та шляхів ії̈ інвестування, розвитку, організації, потрібно підвести підсумки правозастосувальної практики щодо виконання Закону України «Про морські порти» та підзаконних актів, принаймні стосовно діяльності портових операторів та операторів терміналів у договірних правовідносинах 3 вантажовласниками та іншими суб'єктами морського бізнесу.
У сфері поліпшення надання послуг портових операторів - стивідорів необхідно також усунення різноманітних недоліків. Але вишукування проблем у цій галузі її не оновить і не дасть поштовху для подальшого розвитку. Ефективною може стати багатостороння допомога у стивідорній діяльності, а також залучення нових клієнтів та інвестицій.

у будь-якій діяльності $\epsilon$ недоліки, які необхідно усувати і перспективи, які потрібно розвивати. Діяльність стивідорних компаній також $\epsilon$ діяльністю $з$ перспективами розвитку, але тільки цілком усунувши перешкоди, можливо одержати збільшення суднопотоку, покращити якість портових послуг, вийти на міжнародний рівень і конкурувати з іншими морськими портами Східної Європи. Морські порти нашої країни мають велике майбутнє, потужний кадровий потенціал, який у майбутньому, за умов обрання правильного шляху розвитку, відновить вітчизняні морські порти у колі лідерів портової галузі.

\section{ЛITEPATУPA:}

1. Кодекс торгового мореплавства України : Закон України від 23 травня 1995 р. Відомості Верховної Ради України. 1993. № 47.

2. Про морські порти України: Закон України від 17 травня 2012 р. № 4709-УІ. Офіційний вісник України. 2012. № 45.

3. Про затвердження Правил надання морських послуг у портах України : Наказ Міністерства інфраструктури України від 5 червня 2013 р. № 348. Офіційний вісник України. 2013. № 65.

4. Гришина Л.О., Карась П.М., Філіпішина Л.М. Тенденції, проблеми та перспективи розвитку морегосподарського комплексу України в умовах євроінтеграції. Науковий вісник УнУ. 2019. Вип. 24. 4. 1. С. 131-135.

5. Морська доктрина України на період до 2035 року. База даних «Законодавство України». URL: https://zakon.rada.gov.ua/laws/show/1307-2009-\%D0\%BF\#Text

6. Манаєнко I.М., Просяник I.В. Особливості зовнішньоекономічної діяльності вітчизняних підприємств в умовах євроінтеграції. Науковий вісник Ужгородського національного університету. 2018. Вип. 18. Ч. 3. С. 11-14.

7. Рыженкова Н. Грузооборот в портах Украины вырос на 3,7\%. Порты Украины. 2020. № 8 (200). C. 36-41.

8. Статут Державного підприємства «Адміністрація морських портів України». URL: https:// mtu.gov.ua/files/\%D0\%A1\%D1\%82\%D0\%B0\%D1\%82\%D1\%83\%D1\%82\%20.

9. Джемал Инаишвили: «Мы видим Херсонский порт как крупный региональный хаб». Порты Украины. 2020. № 6(198). С. 8-9.

10. Работнев Владимир: «Каким быть морфлоту Украины в 2030 году». Порты Украины. 2020. № 6(198). С. 20-24.

11. Оновлена Стратегія розвитку морських портів до 2038 року від 23 грудня 2020 p. URL: http://www.uspa.gov.ua/pres-tsentr/novini/novini-galuzi/18137-skhvalenoonovlenu-strategiyu-rozvitku-morskikh-portiv-do-2038-roku-mininfrastrukturi 